\title{
Erratum to: Contemporary and Scenario Changes in River Runoff in the Don Basin
}

\author{
A. G. Georgiadia, * I. P. Milyukova ${ }^{a}$, and E. A. Kashutina ${ }^{a}$ \\ ${ }^{a}$ Institute of Geography, Russian Academy of Sciences, Moscow, 119017 Russia \\ *e-mail: galex50@gmail.com \\ Submitted January 18, 2021; accepted for publication January 18, 2021
}

DOI: $10.1134 / \mathrm{S} 0097807821120010$

The surname of the first author should read Georgiadi.

The original article can be found online at https://doi.org/10.1134/S0097807820060068 